\title{
Biodegradation of Anionic Surfactants from Oilfield Detergents in Aquatic Systems
}

\author{
Anwuli U. Osadebe*, Chinelo A. Onyiliogwu, Gideon C. Okpokwasili \\ Department of Microbiology, University of Port Harcourt, Nigeria
}

Copyright $\mathrm{C} 2018$ by authors, all rights reserved. Authors agree that this article remains permanently open access under the terms of the Creative Commons Attribution License 4.0 International License

\begin{abstract}
The biodegradability of anionic surfactants in oilfield detergents was investigated using water samples from the New Calabar River and Tap water. The detergents analyzed were D.D-Y, D.G-X, SUR-500, SW-1000 and Bio-Boost. The anionic surfactant, Sodium dodecyl sulphate (SDS) was employed as a reference. The total heterotrophic counts in the water samples were determined using the spread plate technique while the detergent-utilizers were investigated using Mineral salt agar. Biodegradation was evaluated by monitoring Methylene Blue Active Substance (MBAS) using the "River die-away" method. The percentage MBAS remaining, after the 28 day study period, in increasing order was SDS $<$ SUR-500 $<$ SW-1000 < Bio-boost $<$ D.D-Y $<$ D.G-X; SDS was the most biodegraded. SUR-500, SW-1000 and Bio-boost supported the highest growth of utilizers. The detergent-utilizing bacteria isolated belonged to the genera Proteus, Acinetobacter, Enterobacter, Staphylococcus, Bacillus, Pseudomonas, Arthrobacter, Corynebacterium and Micrococcus. A steady increase in total viable count, $\mathrm{pH}$ and optical density was observed during biodegradation. The detergents tested could be considered biodegradable as they had an average of $91 \%$ $97 \%$ primary biodegradation at the end of the 28 day test period which is within the biodegradability standards set by the Soap and Detergent Association (SDA) and the Organisation for Economic Co-operation and Development (OECD).
\end{abstract}

Keywords Anionic Surfactant, Biodegradation, Heterotrophic Bacteria, Oilfield Detergent, Rivers, Aquatic Ecosystem

\section{Introduction}

Oilfield detergents are a group of chemical compounds extensively employed in the petroleum industry during the various stages of the oil production chain including oil extraction, transportation, tank cleaning, oil waste treatment and as demulsifying and anti-corrosion agents [1 - 4]. The use of these oilfield detergents during the oil production process is standard practice in the Nigerian oil and gas industry. Surfactants are the active components of these compounds; these surfactants may be anionic, cationic, non-ionic or amphoteric however only anionic and non-ionic surfactants are utilized as crude oil dispersants [5]. Oilfield detergents will normally contain one or more surfactants in combination with an organic solvent. These detergents have a strong bearing on the quality of oil recovered during extraction. They boost oil flow properties and filtration volume, enhancing penetration and extraction during the oil production process [6]. They are further used in the control of oil spills in both soil and water environments to reduce interfacial tension between oil and water increasing the number of small droplets and thus, the available surface area for dispersion and degradation [7, 8]. They enhance pollutant desorption and availability $[9,10]$. Detergents may be used on their own or in combination with other compounds. Drilling muds for instance often include detergents and dispersants as their main components in addition to bactericides, additives for $\mathrm{pH}$ control, defoamers, deflocculants, slurry extenders, retarders, viscosifiers and thinners $[11,12]$.

Records show that between 1990 and 1999, approximately 600, 000 tons of petroleum was released into the world's oceans from natural seepage alone $[8,13]$. Microbial degradation plays a key role in the elimination of spilled oil from any environment; the use of detergents referred to as dispersants enhances the process [14]. Oil spill dispersants were first used on a large scale during the clean-up of the Torrey canyon spill in the United Kingdom in 1967 [15]. The use of dispersants has become the most frequently applied spill management technique even though their use has been trailed with controversy regarding both long- and short-term environmental impact and public health concerns. One study found that the combination of crude oil and a named dispersant was more toxic than that of crude oil alone [16]. This increased toxicity of the crude oil - dispersant combination has been 
confirmed by other reports. It was confirmed to be 52 times more toxic in certain cases [17]. High surfactant concentrations have been found to impact the integrity of the bacterial membrane $[1,18]$. With higher organisms, the surfactants found in oilfield dispersants are bio-transformed and eliminated via their gall bladder [19]. The use of the oilfield dispersant Corexit for the management of an oil spill in the gulf has been plagued by public health and ecological challenges from rectal bleeding, hyper-allergies to processed foods, rapid weight loss, migraines, heart palpitations, multiple chemical sensitivity and cancer to disruption of whole ecosystems $[15,17]$. Oilfield detergents with high aromatic compound content have been recognized as highly toxic to marine life [15]. Oilfield dispersants have been found to accumulate in the water column sinking with oil to the sea floor which especially impacts on the highly environmentally sensitive coral reefs [17]. Certain researchers maintain that without the use of these dispersants, the breakdown of complex hydrocarbon compounds would take longer [3]. However, the persistence of oilfield detergents makes them environmentally significant. Biodegradability and the accompanying environmental toxicology problems are major concerns in the use of detergents in oil production and dispersants to manage petroleum spills in any environment.

The disposal of these detergents in developing countries is often poorly regulated. Drilling muds in some cases are discharged untreated into lined landfills ultimately often still finding their way into the aquifer or surrounding bodies [6]. The aquatic systems across large regions are linked and are home to a wide variety of organisms sensitive to any changes in the chemical composition of the waters in which they live. There is a strong likelihood that any pollutant disposed of into rivers and streams will ultimately end up in the seas and oceans. Furthermore, a large amount of oil drilling is done offshore; this increases the scope of any potential environmental impact. Biodegradability studies are fundamental to the better understanding of the environmental risks involved in the use of these chemicals. There are both acute and chronic public health implications as well, seeing that these aquatic systems serve as source of recreation and drinking water to several surrounding settlements in developing countries. The degradation of the global water supply that accompanies the discharge of these chemicals into the aquatic ecosystem cannot be over-emphasised. Apart from the biological and public health impacts, there are also physical and chemicals implications within the aquatic ecosystem including poor light penetration and increased temperature, increased oxygen consumption and changes in the loading rates of dissimilatory nutrients $[6,20]$.

The need for biodegradability studies stems from the regular disposal of these chemicals into the aquatic ecosystem as well as the use of oilfield detergents and dispersants in open environments commonly across large distances which essentially mean that they will eventually get washed into neighboring water bodies or seep into the aquifer where they may persist. This study aimed to look at the biodegradability of commonly used oilfield detergents.

\section{Materials and Methods}

\subsection{Sources of Samples}

The river water samples used in this study were obtained from the New Calabar River located about $200 \mathrm{~m}$ west of the University of Port Harcourt, Nigeria while the tap water was obtained from the laboratory taps of the university. The detergents tested were manufactured as follows: SW1000 (a dispersant) by Heritage Laboratories, Pennsylvania, USA; SUR500 (a dispersant) by White Resources, Inc., Texas, USA; Bio Boost (a dispersant) by Tetrahedron, Inc., Baltimore, Maryland while D.D-Y (a drilling agent) and D.G-X (a degreaser) were obtained from the University of Port Harcourt, Nigeria. Sodium dodecyl sulfate (SDS) obtained from Sigma Chemical Company St. Louis, USA was employed as the standard.

\subsection{Total Aerobic Heterotrophic Microbial Counts}

The dilution plate technique was used. Samples of the river and tap water were serially diluted before inoculating selected dilutions unto nutrient agar plates in duplicates. The plates were then incubated at room temperature for 48 hours after which colony counts were taken.

\subsection{Characterization of Detergent-Utilizing Microorganisms and Determination of Counts}

The numbers of microorganisms in the river water and tap water samples that could grow on agar medium containing a test detergent as the sole carbon source were determined. The agar medium contained, per liter of distilled water: $\mathrm{NaCl}, 5.0 \mathrm{~g} ; \mathrm{KCl}, 0.6 \mathrm{~g} ; \mathrm{MgSO}_{4} .7 \mathrm{H}_{2} \mathrm{O}, 7.0 \mathrm{~g}$, $\mathrm{NH}_{4} \mathrm{NO}_{3}, 1.0 \mathrm{~g}$; Agar, 20.0g; test detergent, $3 \mathrm{mg}$. The $\mathrm{pH}$ was adjusted to neutral. Serial dilutions of the river water samples were obtained and $0.1 \mathrm{ml}$ aliquots of the dilutions were plated out in duplicate onto the detergent agar medium using the spread plate technique. The same dilution regimen was also carried out for the tap water. The plates were incubated at room temperature for 48 hours. Organisms growing on the plates were counted, isolated and purified for characterization and identification. Control plates consisted of agar without the test detergents inoculated with the river and tap water samples. Extensive identification was done using Gram's staining, biochemical testing and macroscopic examination according to recommendation of Gerhardt et al. [21]. 


\subsection{Methylene Blue Active Substance (MBAS) Test}

The method of APHA [22] was used. Ten separatory funnels were prepared with $0.1 \mathrm{ml}, 3.0 \mathrm{ml}, 5.0 \mathrm{ml}, 7.0 \mathrm{ml}$, $9.0 \mathrm{ml}, 11.0 \mathrm{ml}, 13.0 \mathrm{ml}, 15.0 \mathrm{ml}$ and $20.0 \mathrm{ml}$ of individual solutions of SDS $(10 \mu \mathrm{g} / \mathrm{ml})$ and each test detergent sample $(30 \mu \mathrm{g} / \mathrm{ml})$. To these solutions, $1 \mathrm{M} \mathrm{NaOH}$ was added to make it alkaline. Phenolphthalein was used as indicator. Following the addition of $10 \mathrm{ml}$ chloroform and $25 \mathrm{ml}$ Methylene blue reagent, the set up was shaken vigorously for 30 seconds. Any gas produced was released through the delivery tube. The tubes were left to stand undisturbed for thirty minutes to achieve separation. The chloroform layer was then drawn off and extracts were collected in a $100 \mathrm{ml}$ Erlenmeyer flask. Extraction was carried out three times using $10 \mathrm{ml}$ chloroform each time. The extracts were added back to each funnel and $50 \mathrm{ml}$ of the wash solution was added to each funnel. The funnels were shaken vigorously for 30 seconds and again left to stand for 30 minutes. The chloroform extracts were later diluted to the $100 \mathrm{ml}$ mark with chloroform. The volumetric flasks were finally shaken in order to ensure uniform mixing. The absorbance of the chloroform extracts were measured at $390 \mathrm{~nm}$ against blank chloroform. Calibration curves of test detergent concentration against absorbance were plotted. Tests were also carried out using sterilized river water inoculated unto mineral salt agar containing the test detergents as the sole carbon source.

\subsection{Determination of the Extent of Primary Biodegradation of Detergent using River Die-Away MBAS Method}

The river die-away method was used to determine the extent of biodegradation of the different detergent brands. Known quantities of SDS and the test detergents were added to fresh water in order to obtain concentrations of $1 \mu \mathrm{g} / \mathrm{ml}$ for SDS and $3 \mu \mathrm{g} / \mathrm{ml}$ for the detergents being tested. From these stock solutions, $10 \mathrm{ml}$ was diluted to $1 \mathrm{~L}$ using distilled water and $300 \mathrm{ml}$ from this solution was added to $1200 \mathrm{ml}$ river water. The solutions were incubated at room temperature for 28 days; $100 \mathrm{ml}$ were drawn for MBAS analysis every four days. The residual surfactant concentrations were read off the calibration curves. Samples from here were also used to determine total viable counts via the spread plate technique.

\section{Results and Discussion}

As shown in Table 1, the total aerobic heterotrophic counts obtained were $2.43 \times 10^{6}$ and $1.01 \times 10^{5}$ for river water and tap water respectively. The lower numbers seen in tap water is expected as tap water will normally undergo treatment to lower microbial loads. Results showed that SDS had the highest microbial load from both river water and tap water while D.D-Y and D.G-X supported the lowest counts in both groups of water samples though not that much lower than the other detergents being examined (Figure 1). Only a small percentage of approximately 2.59 $2.96 \%$ of the microorganisms in river water were able to utilize the test detergents. For SDS, this figure is only slightly higher at $3.46 \%$ of the total heterotrophic count in river water. This raises strong concerns regarding the discharge of these detergents directly into aquatic systems as only a limited number of microbial groups are able to break them down.

Table 1. Total Aerobic Heterotrophic Count

\begin{tabular}{cc}
\hline Sample & Mean Count (cfu/ml) \\
\hline River Water & $2.43 \times 10^{6}$ \\
Tap Water & $1.01 \times 10^{5}$ \\
\hline
\end{tabular}

The detergent-utilizing bacteria isolated belonged to the genera Proteus, Acinetobacter, Enterobacter, Staphylococcus, Bacillus, Pseudomonas, Arthrobacter, Corynebacterium and Micrococcus as highlighted in Figure 2. Bacillus, Arthrobacter, Pseudomonas and Staphylococcus had the highest frequencies of occurrence. Several studies have highlighted the dominance of species of Pseudomonas in surfactant degradation [23 - 26]. Enterobacter, Bacillus and Proteus are also identified as surfactant utilizers [23, 26].

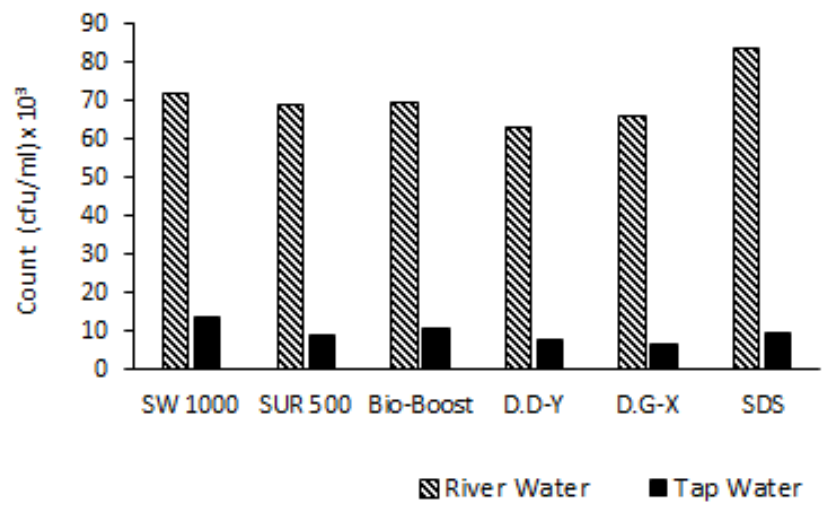

Figure 1. Detergent-Utilizer Counts in River Water and Tap Water

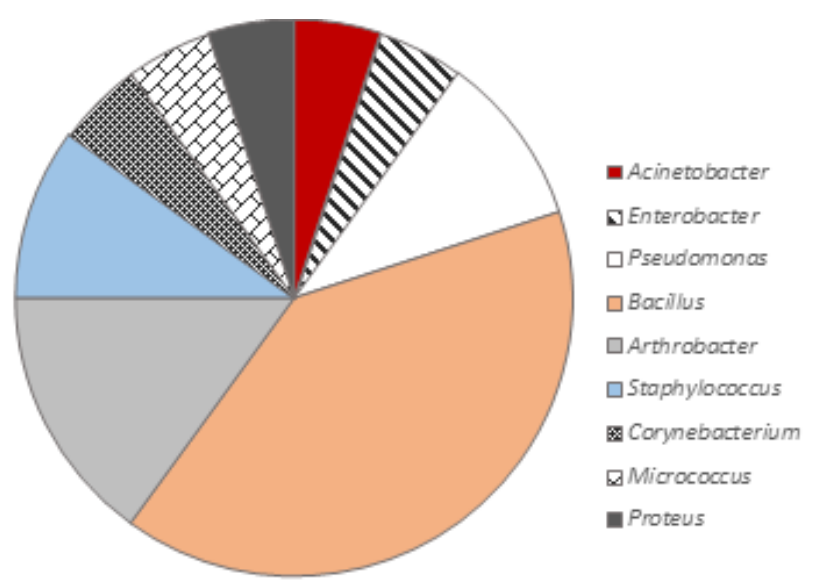

Figure 2. Distribution of Detergent Utilizers Isolated 
Nrior and Wosa [5] found that surfactants were readily utilized by Pseudomonas, Proteus, Micrococcus, Bacillus, Rhizopus, Aspergillus and Penicillium with total counts of $1.58 \times 10^{6}-2.51 \times 10^{6} \mathrm{cfu} / \mathrm{ml}$ following a 20-day incubation period. The dominance of Gram positive microbes has been attributed to the presence of peptidoglycan in their cell walls which provide added resistance to the stress posed by the surfactants. Other studies list this peptidoglycan content as a disadvantage stating that the utilization of surfactants by Gram positive bacteria is limited [18, 27, 28]. The spore-forming ability of Bacillus is thought to play a crucial role in its ability to excel in the biodegradation of the surfactants from oilfield detergents [28].

The changes in the total viable counts as biodegradation of the detergents proceeded are shown in Figure 3. SDS supported the highest total heterotrophic bacterial count $\left(2.5 \times 10^{2} \mathrm{cfu} / \mathrm{ml}\right)$ but the test dispersants had higher counts for dispersant-utilizing bacteria with maximum counts of $7.97 \times 10^{5} \mathrm{cfu} / \mathrm{ml}, 7.71 \times 10^{5} \mathrm{cfu} / \mathrm{ml}$ and $7.34 \times 10^{5} \mathrm{cfu} / \mathrm{ml}$ for SUR 500, SW 1000 and Bio-Boost respectively on Day 28. These values are lower than those observed in a prior study [5] but are in agreement with the observations of
Okpokwasili and Nnubia [29] that oil spill dispersants tend to support mild increases in the growth of certain heterotrophic marine bacteria. This increase may be due to the utilization of the detergents as sources of carbon for energy and biomass production. The concentration of phosphates incorporated into the different detergents also plays a role here as phosphates support microbial growth. It should be noted however that the detergent that supports the highest microbial growth may not necessarily contain the most readily biodegraded surfactant [26]. Higgins and Burns [30] support this view stating that the relationship between microorganisms and surfactants is relatively complex and usually involves multiple factors. A period of acclimatization is observed where growth rate is initially slow. During this period, the organisms adapt to the environmental stressor. They then synthesize the required enzymes for degradation of the detergent. The growth profiles of the detergent utilizers are illustrated in Figure 4; this growth cycle is opined to be indicative of the biodegradation rates. When the counts are highest, biodegradation has been found to be at its optimum [31]. The stationery phase is reached at about Day 8 of the study.

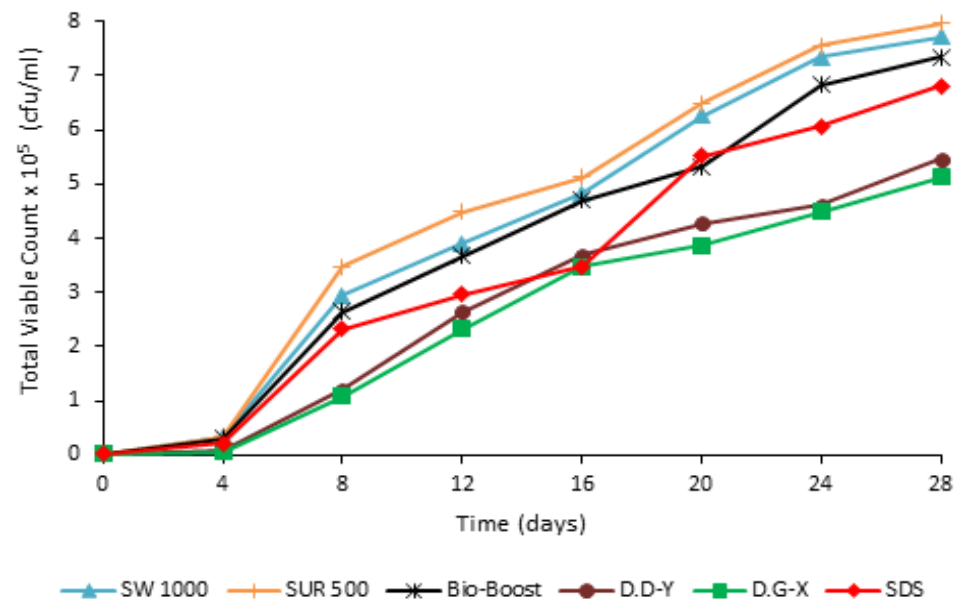

Figure 3. Variation in TVC of Detergent-Utilizers during Biodegradation

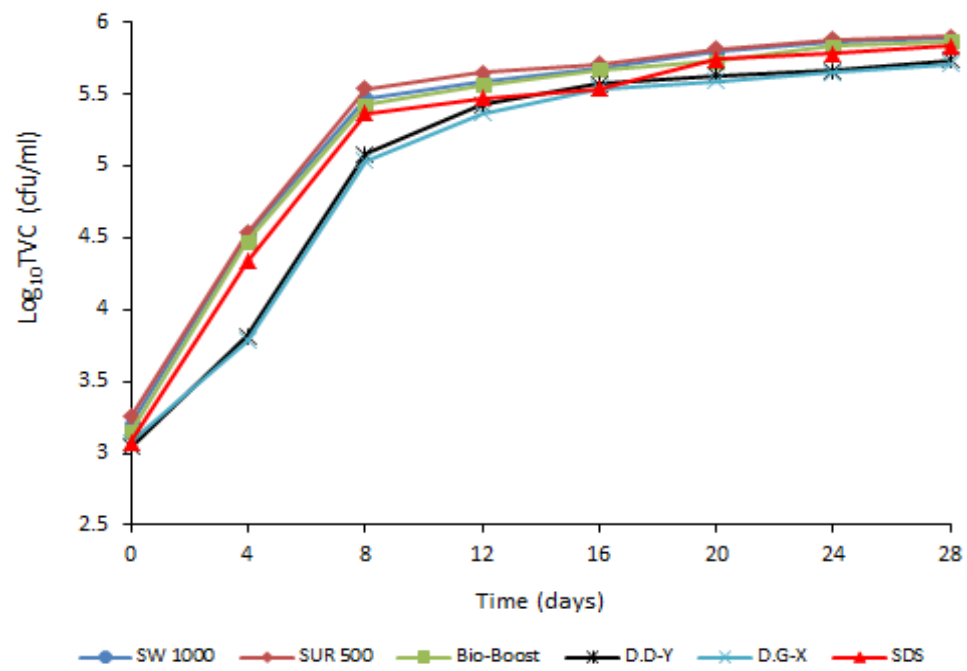

Figure 4. Growth Profile of Detergent-Utilizers 
Changes in $\mathrm{pH}$ are recorded in Figure 5. The media became more basic as degradation proceeded. There was a general increase from $7.0-7.6$ on Day 0 to $9.0-9.5$ on Day 28. The curve shows an initial rise and then a leveling off or in some cases a very gradual drop. The changes in $\mathrm{pH}$ are thought to indicate the release of metabolites into the system as biodegradation progressed. The observed drop could be as a result of utilization of the by-products by the microorganisms or production of secondary more acidic metabolites. The calibration curves of the different test detergents after the absorption of chloroform extracts are shown in Figure 6. The results of the biodegradation tests of the detergents after the 28 -day incubation period at room temperature using the river die-away technique are outlined in Figure 7. The figure represents the "die-away" process for the test detergents. It is observed that SDS and SUR500 "died away" the most closely followed by SW1000, Bio-Boost, D.D-Y and then D.G-X. Generally, all the test detergents demonstrated biodegradation levels of over $90 \%$ which is well above the OECD standard of $80 \%$ primary degradation [32] and only just above the SDA [33] standard of $90 \%$ (Figure 8). Nrior and Wosa [5] recorded a maximum biodegradation of $78.8 \%$ in oilfield dispersants incubated over 20 days while Baumam et al. [34] recorded relatively low biodegradation values of $50 \%$ for non-ionic surfactants. The composition of the individual detergents plays a pertinent role in extent of biodegradation of the detergent observed within any environment [28]. When biodegradation of the test detergent using sterile and non-sterile river water were compared (Figure 9); the set-up with sterile river water showed no degradation while degradation was observed in the set-up with non-sterile river water. This establishes that the degradation observed in this study is as a result of the activity of microorganisms in the water samples.

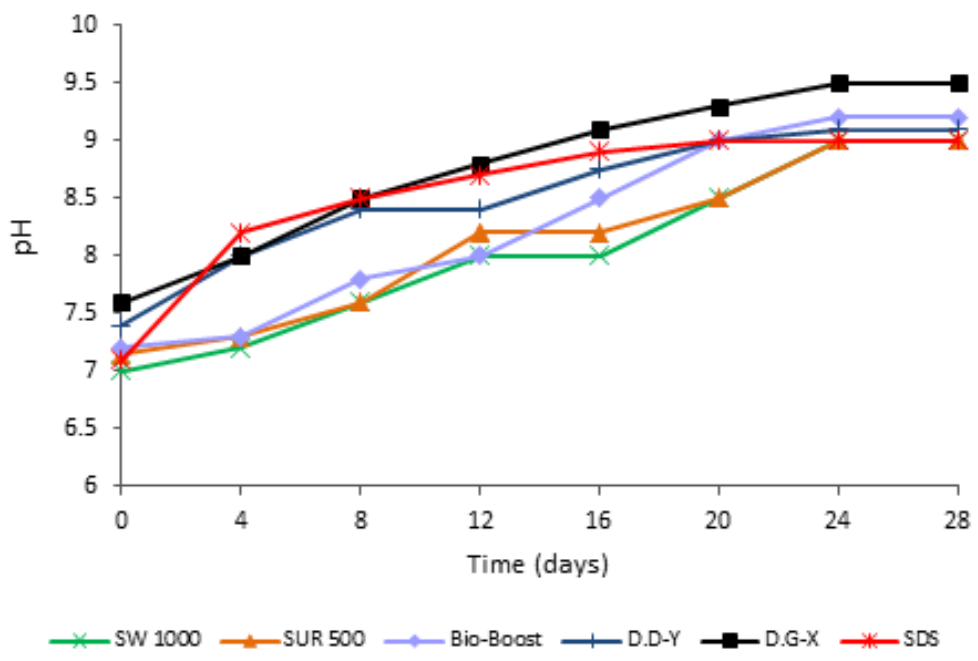

Figure 5. Variation in $\mathrm{pH}$ during Biodegradation

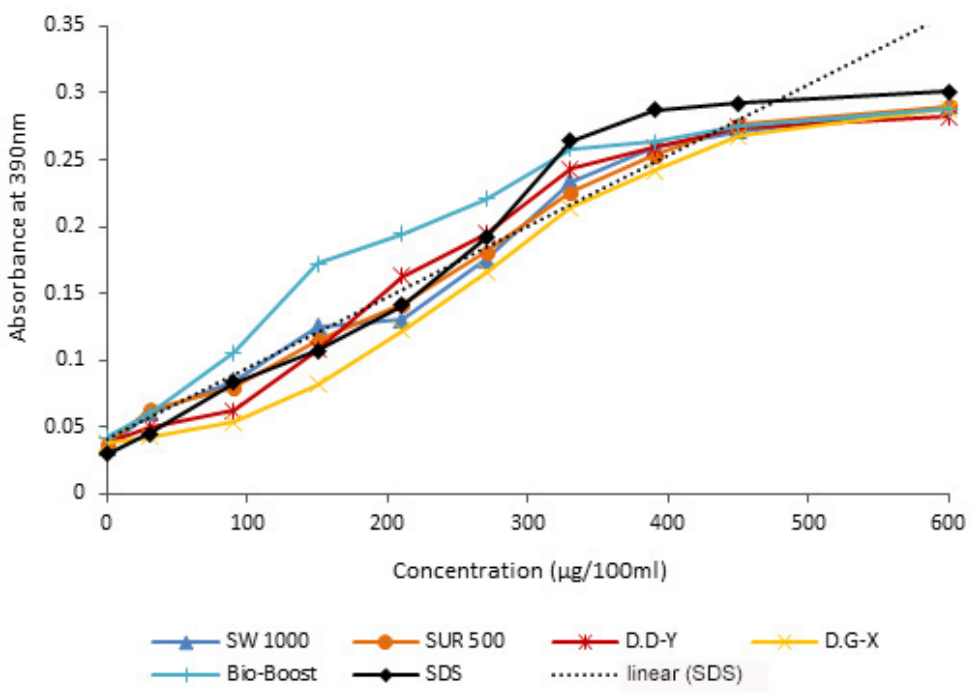

Figure 6. Calibration Curves for the Test Detergents 


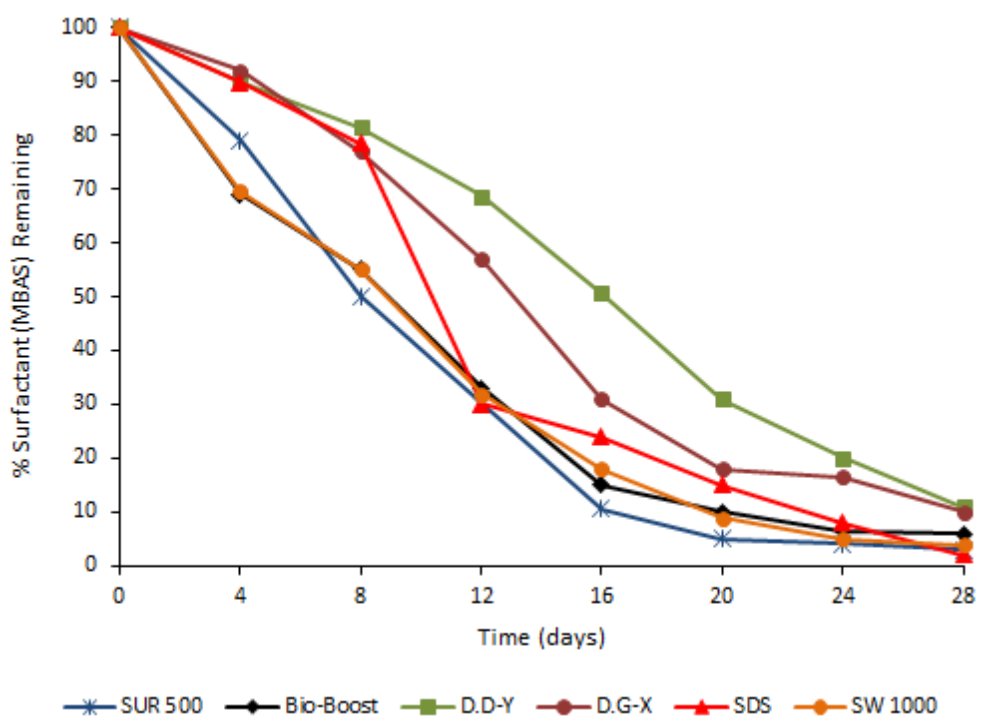

*MBAS - Methylene Blue Active Substance

Figure 7. Biodegradation of the Detergents Using River Die-Away Method

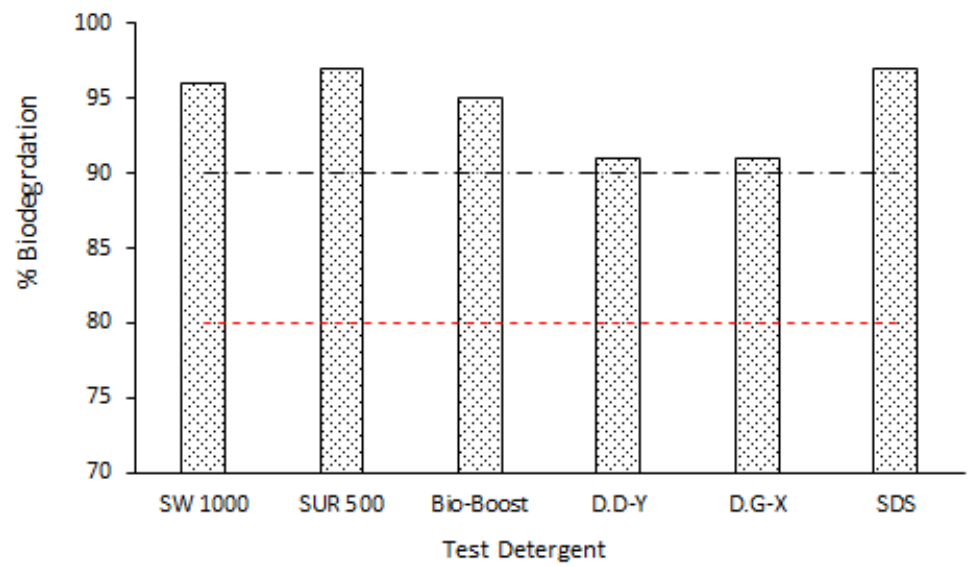

Detergent -.... - OECD Standard _. - - - SDA Standard

*OECD - Organisation for Economic Co-operation and Development; SDA - Soap and Detergent Association

Figure 8. Primary Biodegradation Observed after 28 Days

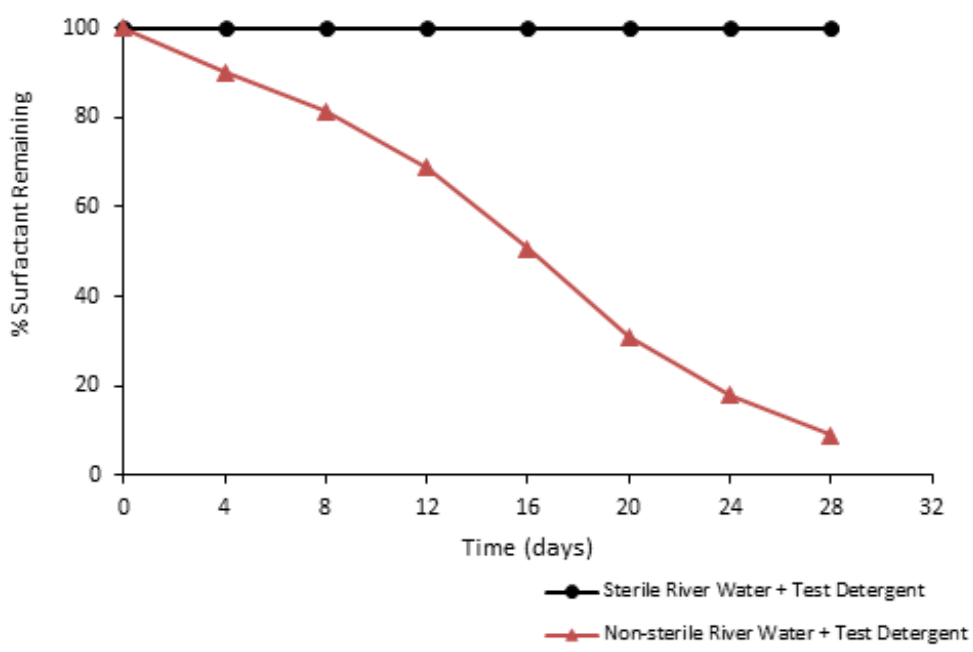

Figure 9. Biodegradation Results Using Sterile and Non-sterile River Water 
Most surfactants are readily degraded by microbes under aerobic conditions with slower rates under anaerobic conditions [35, 36]. Results from different studies suggest that the fate of surfactants in oilfield detergents is highly dependent on concentration, composition, chemical properties, microorganisms present in the environment and the methods used to stimulate biodegradation $[28,34,37$ 39]. The size and shape of the side chain impacts on a detergent's readiness to biodegrade. The greater the distance between the sulfonate group and the end chain, the greater the ease of degradation while a quaternary carbon at the far end of the chain interferes with degradation [40]. Some synthetic surfactants have been known to show decreased biodegradation as a result of the toxic effect of either their constituent surfactants or their degradation by-products $[41,42]$.

\section{Conclusions}

Since the use of oilfield detergents is essential to the petroleum industry, it is pertinent to ensure that these compounds exert minimal impact on the environment. While the oilfield detergents tested in this study meet the required criteria of $80 \%-90 \%$ biodegradability as expected by international governing bodies, their continuous discharge into any system should be discouraged as it would result in the rapid proliferation of the detergent utilizers in that environment upsetting the natural balance in the ecosystem. The use of natural products should be encouraged over synthetic compounds. Regular biodegradability testing is imperative even for previously approved detergents. Readily biodegradable oilfield detergents provide clean technology options for environmental management. Biodegradability levels outside set standards would certainly impact negatively on aquatic systems and associated flora and fauna. The ideal oilfield detergent would be one with low level inherent toxicity that is not only effective, rapidly solubilising oil but readily biodegradable by indigenous microorganisms as well. There is a need for government to get involved in environmental management to ensure the use of eco-friendly detergents in the oil and gas sector. Reform of appropriate policies to ensure the use of suitable detergents and dispersants would go a long way. Sector regulators must be proactive in enforcement. It should be mandatory to test these detergents for biodegradability prior to use considering the potential impact on the ecosystem and human health.

\section{REFERENCES}

[1] Lee, K., 2012, Degradation of Dispersants and Dispersed Oil [online]. Retrieved from https://crrc.unh.edu/sites/crrc.unh.edu/files/lee-dispdegradat ion.pdf, accessed $10^{\text {th }}$ December, 2017.

[2] Bustamanté, M., Duran, N., Diez, M. C. Biosurfactants are useful tools for the bioremediation of contaminated soil, a review. Journal of Soil Science and Plant Nutrition 12 (4), $667-687,2012$.

[3] Uzoigwe, C. I., Okpokwasili, G. C. Biodegradation of Oil Spill Dispersants in Natural Aquatic Ecosystem. International Journal of Physical Sciences 7 (38), 5477 $5484,2012$.

[4] Christofi, N., Ivshina, I. B. Microbial Surfactants and their use in field studies of soil remediation. Journal of Applied Microbiology 93, 915 - 929, 2002.

[5] Nrior, R. R., Wosa, C. Biodegradation of oil spill dispersant in brackish water ecosystem of the Niger delta, Nigeria. Current studies in comparative education science and technology 3 (1), 187 - 201, 2016.

[6] Nrior, R. R., Odokuma, L. O. Comparative toxicity of drilling fluids to marine water shrimp (Mysidopsis bahia) and brackish water shrimp (Palaemonetes africanus). IOSR Journal of Environmental Science, Toxicology and Food Technology 9(7): 73 - 79, 2015.

[7] Pekdemir, K., Copur, M., Urum, K. Emulsification of crude oil - water systems using biosurfactants. Proc. Safety environ. Protect. 83, 38 - 46, 2005.

[8] NRC, National Research Council, Oil Spill Dispersants. The National Academic Press, Washington DC, USA, 2005.

[9] Rahman, K. S. M., Banat, I. M., Thahira, J., Thayumanavan, T., Lakshmanaperumalsamy, P. Bioremediation of gasoline contaminated soil by a bacterial consortium amended with poultry litter, coir pith and rhamnolipid biosurfactant. Bioresource Technology 81, 25 - 32, 2002.

[10] Volkering, F., Breure, A. M., van Andel, J. G., Rulkens, W.H. Influence of non-ionic surfactants on bioavailabilty and biodegradation of polycyclic aromatic hydrocarbons Applied and Environmental Microbiology 61, 1699 - 1705, 1995.

[11] Muhlemann, T. M. Guide to Drilling, Completion and Workover Fluids. World Oil 202: 5, 1986.

[12] Terrens, G. W., Gwyther, D. and Keogh, M. J. Environmental Assessment of Synthetic Based Drilling Mud Discharges to Bass Strait, Australia. Proceedings of the APPEA Conference, Canberra, 8 - 11 March, 1998.

[13] Stout, S. A., Wang, Z. Chemical finger-printing of spilled or discharged petroleum - methods and factors affecting petroleum fingerprints in the environment. In: Wang, Z. and Stout, S. A. (eds.) Oil Spill Environmental Forensics, Fingerprinting and Source Identification. Elsevier, Burlington, Massachusetts, 2018.

[14] Ventikos, N. P., Vergetis, E. O., Psaraftis, H. N., Triantafyllou, G. A high level synthesis of oil spill response equipment and counter measures. Journal of Hazardous Materials 107, $51-58,2004$

[15] Interspill Organisation, Oil Spill Dispersants: Developments in Regulations and Industry Perspectives, 2012 [online]. Retrieved from http://www.interspill.org/previous-events/2012/13-March/p 
dfs/Oil\%20Spill\%20Dispersants\%20-\%20Developments\% 20in\%20Regulations\%20and $\% 20$ Industry $\% 20$ Perspectives. pdf, accessed $27^{\text {th }}$ February, 2018.

[16] Otitoloju, A. A. Evaluation of Crude Oil Degradation under a No-Control and Dispersant Control Settings, Based on Biological and Physical Techniques. International Journal of Environmental Research 4 (2): 353 - 360, 2010.

[17] Devine S., Devine, T., Public Comments on EPA Proposed Rule to Sub-part $J$ of the National Oil and Hazardous Substances Pollution Contingency Plan the Governs the Use of Dispersants. Addendum Report to "Deadly Dispersants in the Gulf: Are Public Health and Environmental Tragedies the New Norm for Oil Spill Clean-ups?" Government Accountability Project (GAP), 2015 [online]. Retrieved from

https://www.whistleblower.org/sites/default/files/GAP\%20 Addendum\%20Report\%20Final.pdf, accessed $27^{\text {th }}$ February, 2018.

[18] Chen, J.; Li, S.; Luo, J.; Wang, R., Ding, W. Enhancement of the antibacterial activity of silver nanoparticles against phytopathogenic bacterium Ralstonia solanacearum by stabilisation. Journal of Nanomaterials 2016, Article ID: $7135852,2016$.

[19] Tolls, J., Kloepper-Sams, P. J., Sijm, D. T. H. M. Surfactant bioconcentration - a critical review. Chemosphere 29, $693-$ 717, 1994.

[20] Nrior, R.R., Odokuma, L.O., Tete, E. Ultimate biodegradation of industrial detergent used in the upstream sector of the Nigeria petroleum industry in freshwater, brackish and marine water. International Journal of Ecotoxicology and Ecobiology 2(4): 134 - 144, 2017.

[21] Gerhardt, P.; Murray, R. G. E.; Costilow, R. N.; Nester, E. W.; Wood, W. A.; Kreig, N. R., Philips, C. B. Manual of Methods for General Biotechnology. American Society for Microbiology, Washington, D.C., 1981.

[22] APHA, Standard Methods for the Examination of Water and Wastewater. $20^{\text {th }}$ Ed. American Public Health Association, Washington D.C., 1998.

[23] Okpokwasili, G.C., Nwabuzor, C. N. Primary biodegradation of anionic surfactants in laundry detergents. Chemosphere 17, 2175-2182, 1988.

[24] Asok, A. K., Jisha, M. S. Biodegradation of the anionic surfactant linear alkylbenzene sulfonate (LAS) by autochthonous Pseudomonas sp. Water Air Soil Pollut. 223, $5039-5048,2012$.

[25] Fathi, G., Janmohammadi, F., Roshani, D. Anionic Surfactant degradation by Pseudomonas in hospital wastewater, case study, Shahid Beheshti Hospital in Abadan city, Iran. Eurasian J. Agric. \& Environ. Sci. 16(6), 1117 1122, 2016.

[26] Okpokwasili, G.C., Olisa, A. O. River water biodegradation of surfactants in liquid detergents and shampoos. Water Research 25, 1425 - 1429, 1991.

[27] Okpokwasili, G. C. and Okorie, B. B. Biodeterioration potentials of microorganisms isolated from car engine lubricating oil. Tribiology International 21: 215 - 220, 1988.

[28] Odokuma, L.O., Okpokwasili, G. C. Role of composition in biodegradability of oil spill dispersants. Waste Management $12,39-43,1992$

[29] Okpokwasili, G. C., Nnubia, C. Effects of oil spill dispersants and drilling fluids on substrate specificity of marine bacteria. Waste Management 7, 515 - 520, 1995.

[30] Higgins, I. J., Burns, R. G. The Chemistry and Microbiology of Pollution. Academic Press, London, 1975.

[31] Ojo-Omoniyi, O. A. Biodegradation of Synthetic Detergents, Chapter 9 In: Chamy, R. and Rosenkranz, F. (eds.) Biodegradation - Life of Science. InTech Open Science Europe, 2013.

[32] Gerike, P. Environmental Impact In: Falbe, J. (ed.) Surfactants in Consumer Products, Theory, Technology and Application. Springer-Verlag, Berlin. p461, 1987.

[33] SDA, The Soap and Detergent Association, A procedure and standards for the determination of the biodegradability of alkyl benzene sulphonate and linear alkylate sulphonate. $J$. Am. Oil. Chem. Soc. 42, 986 - 993, 1965.

[34] Baumam, U., Benz, M., Pletcher, E., Breuker, K., Zenobi, R. Biodegradation of sugar alcohol ethoxylates. Tenside Surfactants and Detergents 36, 288 - 293, 1999.

[35] Ying, G. C. Fate, behaviour and effects of surfactants and their degradation products in the environment. Environment International 32, $417-431,2006$.

[36] Berna, J. L., Cassani, G., Hager, C. D., Rehman, N., Lopez, I., Schowanek, D., Steber, J., Taeger, K., Wind, T. Anaerobic biodegradation of surfactants - a scientific review. Tenside Surfactants and Detergents 44, 312 - 347, 2007.

[37] Lindstrom, J. E., Braddock, J. F. Biodegradation of Petroleum hydrocarbons at low temperature in the presence of the dispersant Corexit 9500. Marine Pollution Bulletin 44, $739-747,2002$.

[38] Owen, S. A., Russell, N. J., House, W. A., White, G. F. Re-evaluation of the hypothesis that biodegradable surfactants stimulate surface attachment of competent bacteria. Microbiology 143, 3649 - 3659, 1997.

[39] Garcia, M. T., Campos, E., Marsal, A., Ribosa, I. Biodegradability and Toxicity of sulphonate-based surfactants in aerobic and anaerobic aquatic environments. Water Research 43, 295 - 302, 2009.

[40] Swisher, R.D. Surfactant Biodegradation. Surfactant Science Series, $2^{\text {nd }}$ Ed. Marcel Dekker, New York, 1987.

[41] Bruheim, P., Bredholt, H., Eimhjellen, K. Effects of surfactant mixtures, including Corexit 9527, on bacterial oxidation of acetate and alkanes in crude oil. Applied and Environmental Microbiology 65 (4), 1658 - 1661, 1999.

[42] Rouse, J. D. Sabatini, D. A., Suflita, J. M., Harwell, J. H. Influence of surfactants on microbial degradation of organic compounds. Critical Reviews in Environmental Science and Technology 24, 325 - 370, 1994. 